\title{
The Blue Jay Bookshelf
}

\section{A NEW DICTIONARY OF BIRDS.}

By A. L. Thompson (Ed.). 1964. McGraw-Hill Book Co., N.Y. 928 p. + 48 plates, $\$ 21.00$.

This book probably contains more information on the world of birds than any other publication in the English language. Its approximately 35,000 entries from "Abdomen" to "Zygomatic Arch" vary in length from a single line to 12 pages ("Sing. ing"). A check of comparable entries with the Encyclopedia Britannica shows that the Dictionary usually gives a longer treatment. Although the work was a centennial project of the British Ornithologists' Union, more than 200 specialists from around the world have made it an authoritative reference written in a style suitable for both amateur bird-watcher and professional ornithologist.

While the emphasis is on text, there are 16 excellent colour plates dealing mainly with differences in plumage by sex, age and season and showing typical birds of zoogeographical regions. There are 70 black and white photographs emphasizing locomotion and breeding behaviour. One outstanding photograph shows a Sanderling (Crocethia alba) running full speed with both feet off the ground. There are also some 250 line drawings depicting typical representatives of families, maps, anatomical details, etc.

There are two types of major articles: those dealing with more than 250 subjects such as form, function, evolution, distribution, ecology, behaviour, relations with man, etc., and those discussing the 158 families of birds. Entries are so precise that one may be misled on the quantity of information given on a subject. For instance, "Distribution Geographical", and "Ecology" are treated in less than nine pages but the 37 articles on various aspects of these two total more than 100 pages. The entry for "Behaviour" is only a few lines but articles on more than 50 aspects of behaviour total almost 100 pages. An indication of preciseness of entries may be seen in the following series: nest, nestbox, nest building, nesting association and nest site selection; plumage, abnormal plumage and plumage variations.

The treatment of families varies in length from one-half page for some families with only one species to six and one-half pages for the 147 species of ducks, geese and swans. Each family is usually discussed in terms of general characters, behaviour, reproduction, social organization, taxonomy, geographical and ecological distribution. The entry for each family is under the vernacular name of a genus that is typical of it, e.g., Corvidae (crows, jays and magpies) are discussed under "Crow", and Accipitridae (hawks, eagles, harriers, etc.) are listed under "Hawks." In addition, a person can determine the generic (and in some cases the specific) name as well as the family of apparently any bird or group of birds with a single common name, e.g., Amakihi, Flicker, Hwamei, Tailorbird. Particularly valuable features are the literature references at the end of many entries and the references to related articles for most entries.

One will find identification of such colloquialisms as "Greenhead", "Honker", "Redwing" and "Specklebelly." There are articles on birds in art, the Bible, folklore, heraldry, music, poetry and Shakespeare. There are entries such as "Bird Watching", "Carrying", "Domestication", "Edible Nests", "Feather Maintenance", "Lincoln Index", "Museum", "Tameness", "Time Measurement" and "Young Birds." There are lists of extinct and 
vanishing birds, of ornithological societies and journals. Beyond the strictly ornithological field are the following: "Climatology", "Mapping", "Meteorology", "Statistical Significance", "Vegetation" and a table for converting from British to metric measurements.

There are some deficiencies. Under "Tracks" is a reference to a 1943 publication but none to O. J. Murie's Field Guide to Animal Tracks (Houghton Mifflin, Boston. 374 p. 1954). Measurements are described but not illustrated. If there is a major defect in the volume, it is one that is inherent in any publication that must rely on 174 authors: uneven treatment. For example, "Climatology" and "Meteorology" occupy more than 16 pages and have 12 references while "Conservation" and "Protection" receive only five pages and one reference. Similarly, six and one-half pages, including 19 literature references, are devoted to the 17 specits of penguins while only two pages and no references are given for 316 species of parrots.

It appears to this reviewer that much of the numerical and distribution data on 158 families hidden in 900 pages of text could have been made more readily available to the reader in a single table. A four- or five-page table with the 158 families and some subfamilies listed in the first column could have standardized and summarized the following types of information in subsequent columns: length, weight, clutch size, incubation periods, some taxonomic characters, and the number of genera and species in each zoogeographic region or on each continent.

The above criticisms are minor. The Dictionary may not prove as attractive to the average bird-watchers as some of the recent lavishly illustrated bird books but anyone who borrows it from a library will have an interesting time browsing through it. And if one wishes to find out about dertum, endysis, Gloger's rule, ingluvies, loomery, miombo or ornithomancy, this dictionary is his best bet.-J. B. Gollop, Saskatoon.

THE WORLD OF THE RED-TAILED HAWK. By G. Ronald Austing. 1964. J. B. Lippincott Co., Philadelphia and New York. \$6.00.

The World of the Red-tailed Hawk is a magnificent interweaving of text and photographs - the text being most pleasingly readable, and the photographs masterpieces.

The author, Ronald Austing, has spent many years studying and photographing Red-tailed Hawks in Ohio. Here, because it is far enough south for Red-tails to winter, he was able to observe "stable pairs in prime habitat" which mate and remain on territory for life, "fringe birds" in poorer habitat which change from year to year, and migrant birds.

With this material at hand he has given us an excellent word picture of the habits, food, appearance and behaviour variations of these different categories of Red-tails-each point being generously illustrated with his superb photographs.

Falconers will be particularly interested in the section in which Austing describes the feeding, training and care of Red-tails. Banders will be equally pleased with his detailed description of techniques and traps that help to make a banding project successful. Yet, in spite of these somewhat more technical aspects, I feel quite sure that even those who are not bird watchers, would enjoy reading this book.-Mary Houston, Saskatoon. 
NORTH AMERICAN FALCONRY AND HUNTING HAWKS. By Frank Lyman Beebe and Harold Melvin Webster. 1965. Box 1484, Denver, Colorado. $8 \frac{1}{2}$ " x 11" "xxi + 315 pages, 12 color and 20 black and white plates. Edition limited to 2,000 volumes. $\$ 25$.

As stated in the author's preface, "no library on this continent has a comprehensive modern work on falconry; nothing has been written, or rather that which has been written either tells nothing or assumes that the reader already knows a great deal." With this before them, the authors then proceed to produce a comprehensive modern work that applies to conditions and species encountered in North America.

The 37 chapters cover such varied topics as "Problems and Legal Aspects", "The Nature of Predation", "The Status of the Peregrine", "Of Molt and Feather", "Diseases and Injuries", "The Future of Falconry." The work is accurate and informative, the style enjoyable. Beebe's illustrations and diagrams leave nothing to be desired. He has succeeded, where other artists fail, in capturing the true spirit of the birds involved. This ability stems from a deep love and understanding of the birds and the sport. This text contains much material on the behaviour, ecology, and status of the birds involved which ought to be of great value to professional wildlife biologists, conservation and game officials, zoologists, ornithologists, and laymen. Some of the material is controversial, but it is presented in logical fashion and the reader is left to formulate his own thoughts on the matter. Much of the material demands a very careful examination by provincial and federal conservation agencies. The soundness of some of the policy set forth will only be determined after experimentation.

In summary, I recommend this excellent and comprehensive volume to those interested in raptorial birds and their management, and in the sport of falconry. In this era of in- secticides and careless gunmen these valuable and interesting birds deserve the attention of all.-Glen A. Fox, Saskatoon.

JOHN JAMES AUDUBON. By Alice Ford. 1964. Norman, New York. Illusstrated with 42 photographs of portraits and plates; cloth, $\$ 10.25$.

John James Audubon is a well known name to naturalists, though there has been a lack of information on some facets of his life and misconceptions about others. The author commences with Audubon's family background of French sea captains and then describes the environment of his birth in San Dominique in the French West Indies. As the story unfolds we find him avoiding Napoleon's conscription in France, dodging British frigates at sea, and becoming an American citizen in Philadelphia. His business adventures were not successful as his artistic temperament seemed more attune to capturing birds and mammals than following laws of commerce. After his bankruptcy he was a taxidermist, painter, and dancing instructor, though he appeared unable to make a good living in this way. His failure to obtain sufficient support for his proposed book, "The Birds of America," sent him to Edinburgh, Liverpool and London, where he obtained the majority of his subscriptions and where his work was printed and published. Descriptions of his rivalry with George Ord of Philadelphia and the controversies that some of his paintings caused prove interesting. The reader begins to realize that at the time of Audubon's book many of the birds and other animals with which we are familiar were unknown and had never been illustrated. Enemies were made owing to differences of opinion upon classifying species which today are commonplace. Information on many subjects of Audubon's life gives the reader a wider knowledge of North American natural history in the first half of the last century.-Tom White, Regina. 